УДК 902.01

https://doi.org/10.24852/2587-6112.2021.3.80.89

\title{
ПРЕДМЕТЫ ВООРУЖЕНИЯ ИЗ БУЛГАРО-ТАТАРСКОГО ГОРОДА ДЖУКЕТАУ
}

\section{(C) 2021 Н.Г. Набиуллин, И.Л. Измайлов}

В научной оборот вводятся материалы исследований предметов вооружения из булгаро-татарского города Джукетау X-XIV вв. («Жукотин» древнерусских летописей), археологические остатки которого располагаются около г. Чистополь Республики Татарстан. Оружие дальнего боя Джукетау включает находки деталей колчана для хранения стрел и сами стрелы (археологически - их железные наконечники), а также, возможно, детали лука. Находки оружия ближнего боя включают перекрестие сабли, вток, боевые ножи. Предметы защитного вооружения представлены фрагментом кольчуги. Выделяются две хронологические группы предметов вооружения, относящиеся к домонгольскому (X-первая треть XIII вв.) и золотоордынскому (вторая треть XIII-начало XV вв.) периодам. В публикации также содержится обзор кратких результатов изучения технологии изготовления небольшой выборки предметов вооружения (в основном, наконечников стрел) из Джукетау по данным металлографических анализов.

Ключевые слова: археология, Республика Татарстан, г. Чистополь, X-XIV вв., Волжская Булгария, Улус Джучи, «Золотая Орда», Джукетау, «Жукотин», предметы вооружения.

\section{ARMAMENT ITEMS FROM THE BOLGAR-TATAR CITY OF JUKETAU}

\section{N. G. Nabiullin, I. L. Izmaylov}

The paper introduces into scientific discourse weapons of the $10^{\text {th }}-14^{\text {th }}$ centuries from the Bolgar-Tatar city of Juketau (referred to as "Zhukotin" in the Old Russian chronicles), the archaeological remains of which were located near the city of Chistopol in the Republic of Tatarstan. The Juketau armament consists of ranged, melee, and defensive weapons. The weapons are subdivided into pre-Mongol (the $10^{\text {th }}-$ first third of the $13^{\text {th }}$ centuries) and Golden Horde (second third of the $13^{\text {th }}$ - the early $15^{\text {th }}$ centuries). The paper features an overview of the results of studying the manufacturing technology of the weapons (arrowheads, mostly) from Juketau on the basis of metallographic analyses.

Keywords: archaeology, Republic of Tatarstan, Chistopol, $10^{\text {th }}-14^{\text {th }}$ centuries, Volga Bolgaria, Ulus of Jochi, "The Golden Horde", Juketau, "Jukotin", armament.

Джукетау - один из основных исторически известных локализованных городов Волжской Булгарии. В эпоху Улуса Джучи Джукетау переживает эпоху своего расцвета, упоминается как «Жукотин» в древнерусских летописях XIV - начала XV вв. Археологические остатки Джукетау X - XIV в. расположены на р. Кама, западнее г. Чистополь Республики Татарстан. Они включают компактно расположенную исторически связанную группу памятников городище Джукетау, Донауровские I (Крутогорское) и II селища, некрополи (Набиуллин, 2001, c. 47-63).

В комплексе вещевого материла Джукетау представлена количественно относительно небольшая, но достаточно выразительная серия предметов вооружения. Основная часть коллекций Джукетау, в составе которых есть и предметы вооружения, сформирована в процессе исследований Т.А. Хлебниковой в 1970-е годы (Хлебникова, 1975), Ф.Ш. Хузина в 1990-е годы, позже Н.Г. Набиуллина. Ныне коллекции хранятся соответственно в

фондах БГИАМЗ и Музея археологии Института археологии им. А.Х. Халикова АН РТ. Небольшие собрания предметов вооружения из Джукетау, имеющие характер подъемного материала, есть в фондах Чистопольского государственного историко-архитектурного и литературного музея-заповедника, Археологического музея Казанского университета (Набиуллин, 2019, с. 24-29). Пока опубликована лишь небольшая часть находок (Хлебникова, 1975, рис. 3: 1-3; 4: 4-7; Набиуллин, 2000 , с. 286-293, 3:11; Руденко, 2002, с. 329 и др.; Семыкин, Набиуллин, 2007; и др.).

Длительное непрерывное существование Джукетау в течение X - XIV вв., в булгарский и золотоордынский периоды, дает возможность прослеживать изменения в наборе оружия в исторической динамике. Однако из-за сильной переработанности культурного слоя памятника лишь небольшая часть культурных остатков имеет надежную стратиграфическую привязку. На сегодняшний день подтверждается предположение об исклю- 

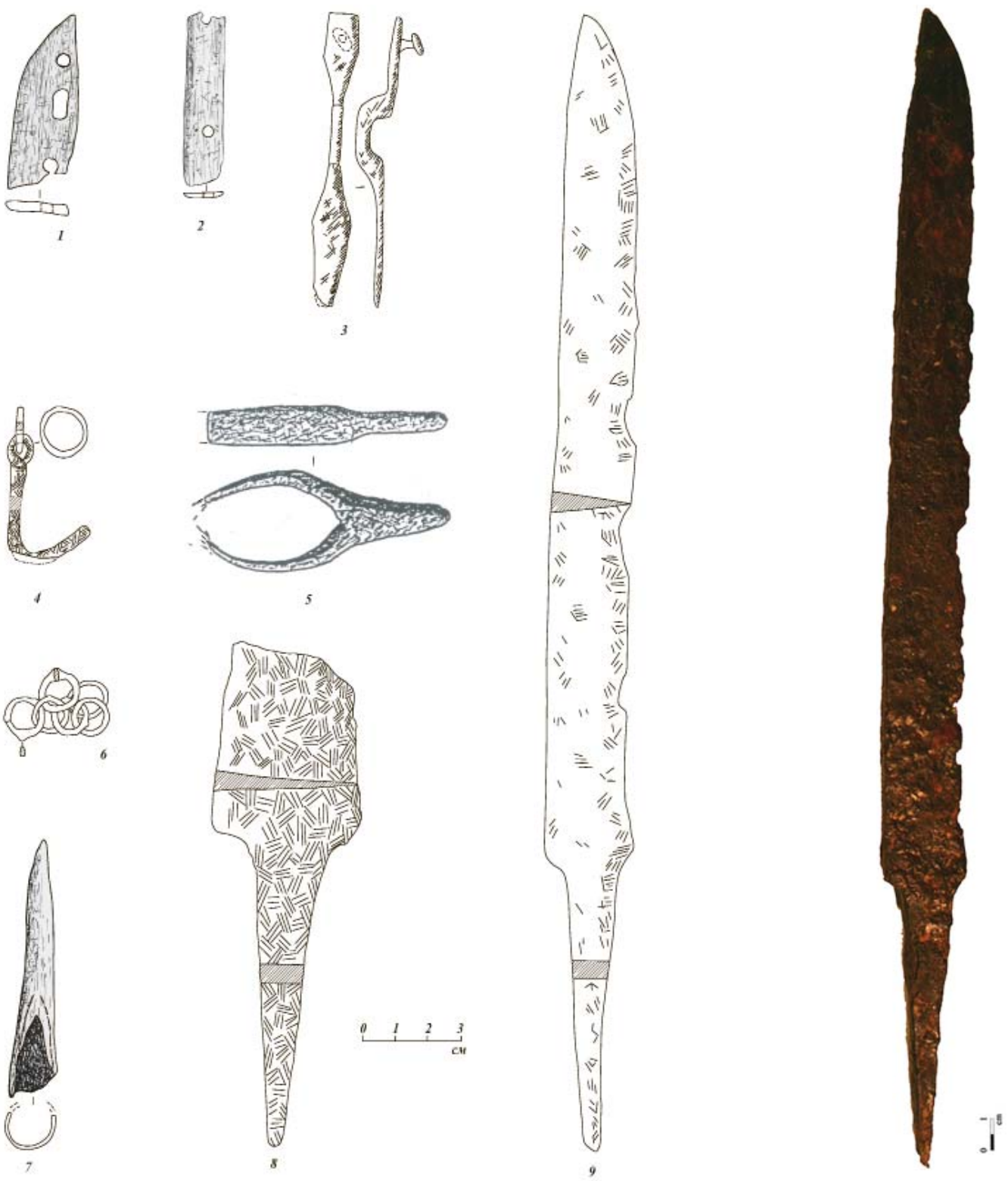

Рис. 1. Предметы вооружения 1, 2 - кость, 3-9 - железо

Fig. 1. Armament items 1, 2- bone, 3-9 - iron

чительно домонгольской датировке (слой III стратиграфической шкалы Джукетау) городища Джукетау и непосредственно прилегающих к нему территорий на правом берегу речки Килевка. Это предполагает изначальную относительно узкую датировку и выявляемого здесь материала, в том числе предметов вооружения, часть которых, в свою очередь, обладает собственно датирующими признаками. Но абсолютное большинство предметов вооружения, как и основная часть всех культурных остатков Джукетау, происходит из расположенного на противоположном берегу речки Килевка Донауровского II селища, которое в X - первой половине XIII вв. являлось одним из городских посадов, а во второй половине XIII - XIV вв. (слой II стратиграфической шкалы Джукетау) - непосредственно территорией города «открытого типа» (Набиуллин, 2001, с. 47-63).

Следуя имеющимся систематизациям (Медведев, 1966; Культура Биляра, 1985; Савченкова, 1996, с. 65-78; Измайлов, 1997; Измайлов, 2006, с. 336-367; Горелик, Измайлов, 2009, с. 396-405; и др.), предметы вооружения Джукетау можно разделить на оружие дальнего и ближнего боя, защитное вооружение.

Оружие дальнего боя из Джукетау включает детали колчана для хранения стрел и сами стрелы (в виде археологических деталей - железных наконечников), а также, возмож- 
Таблица 1. Наконечники стрел Джукетау

Table 1. Juketau arrowheads

\begin{tabular}{|c|c|c|c|c|c|c|c|c|c|c|}
\hline \multirow[b]{2}{*}{ № } & \multicolumn{3}{|c|}{ Длина, мм } & \multirow{2}{*}{\begin{tabular}{|c|} 
Ширина \\
пера по \\
обеим \\
сечениям \\
макс, мм. \\
\end{tabular}} & \multirow{2}{*}{$\begin{array}{l}\text { Bec } \\
\text { (2) }\end{array}$} & \multirow[t]{2}{*}{ Tun } & \multirow[t]{2}{*}{ Слой } & \multirow[t]{2}{*}{ Условия находки } & \multirow{2}{*}{$\begin{array}{c}\text { Место хранения и } \\
\text { шифр }\end{array}$} & \multirow[t]{2}{*}{ Puc. } \\
\hline & Общ. & $\begin{array}{l}\text { Чере- } \\
\text { иок }\end{array}$ & Перо & & & & & & & \\
\hline 1 & 77 & 28 & 49 & $20 \times 2$ & 6,5 & I 1 (37) & $\mathrm{I}$ & Дон. II. П. м. & МА РТ, Дж-1512 & 3,1 \\
\hline 2 & 71 & 25 & 46 & $14 \times 3$ & 6,0 & I $2(38,3)$ & & Гор. P. I (?) & БГИАЗ-245-606 & 3,2 \\
\hline 3 & 91 & 30 & 61 & $20 \times 5$ & 16,3 & I 3 (46?) & $\mathrm{I}$ & Дон. ІІ. П.м. & МА РТ, Дж-1457 & 3,3 \\
\hline 4 & 70 & 20 & 50 & $20 \times 3$ & 11,5 & I 4 (48) & II & Дон. II. Р. V. Б/2, 40 см & МА РТ, Дж-V-94/52 & 3,4 \\
\hline 5 & 118 & 48 & 70 & $23 \times 1$ & 13,5 & I $5(66)$ & II & Дон. II. Р. III. А/2, 35 см & БГИАЗ-588-2266/245 & 3,5 \\
\hline 6 & 95 & 25 & 70 & $30 \times 1$ & 14,0 & I $6(67)$ & $\mathrm{I}$ & Дон. II & МА РТ, Дж-1506 & 3,6 \\
\hline 7 & 108 & 43 & 65 & $22 \times 2$ & 10,5 & I $6(67)$ & II & Дон. II. Р. III. Б/3, 30 см & БГИАЗ-588-2254/245 & 3,7 \\
\hline 8 & $>68$ & 23 & $>45$ & $\sim 15 \times 1$ & $>9$ & I $6(67)$ & Заверш. III & Дон. II. Р. I. & БГИАЗ-245-215 & 3,8 \\
\hline 9 & $>75$ & $>10$ & $\sim 65$ & $20 \times 2$ & $>13$ & I $6(67)$ & $\mathrm{I}$ & Дон. ІІ. П. м. & МА РТ, Дж-1268 & 3,9 \\
\hline $10 *$ & 85 & 20 & 65 & $22 \times 1$ & 12,5 & I $6(67)$ & II & Дон. II. P. IV. Coоp. 1 & $\begin{array}{l}\text { MA РТ, Дж- } \\
\text { IV-92-2232 }\end{array}$ & 3,10 \\
\hline $11 *$ & 120 & 65 & 55 & $35 \times 2$ & 20,0 & I 7 (69) & II & Дон. II. Р. VI. А/2, 40 см & МА РТ, Дж-VI-95/11 & 3,11 \\
\hline 12 & 135 & 72 & 63 & $44 \times 4$ & 32,0 & I $8(72)$ & $\mathrm{I}$ & П. м. & МУГЧ & 3,12 \\
\hline 13 & 73 & 34 & 39 & $13 \times 6$ & 9,2 & II $1(83)$ & $\bar{I}$ & П. м. & МУГЧ & 4,1 \\
\hline 14 & 63 & 32 & 31 & $14 \times 6$ & $>6$ & II $1(83)$ & $\mathrm{I}$ & П. м. & МУГЧ & 4,2 \\
\hline 15 & 65 & 33 & 32 & $12 \times 6$ & 6,7 & II $1(83)$ & & Гор. Р. I (?) & БГИАЗ-245-874 & 4,3 \\
\hline 16 & 67 & 30 & 37 & $13 \times 8$ & 8,0 & II $1(83)$ & III & Гор. P. VII. Coop. 1 & MA РТ, Дж-99-VII/10 & \\
\hline 17 & 58 & 19 & 39 & $10 \times 6$ & 6,1 & II $1(83)$ & & Дон. II ? & БГИАЗ-245-1310 & 4,4 \\
\hline 18 & - & - & $\sim 40$ & $12 \times 3 * *$ & $>15$ & II $1(83)$ & & Гор. Р. I (?) & БГИАЗ-245-982 & 4,5 \\
\hline 19 & 73 & 30 & 43 & $11 \times 10$ & 6,8 & II $1(83)$ & $\bar{I}$ & Дон. II. Р. V. Б/4, 20 см & МА РТ, Дж-V-94/53 & 4,6 \\
\hline 20 & $>54$ & $>12$ & 42 & $14 \times 5^{* *}$ & 8,8 & II $1(83)$ & I & Дон. II. П.м. & АКУ-250-88/42 & 4,7 \\
\hline 21 & 55 & $>22$ & 33 & $13 \times 7$ & 7,4 & II 1 (83) & III & Дон. II. P. VI. Coоp. 3a-1 & MA PT, Дж-VI-96/242 & \\
\hline 22 & 60 & 23 & 37 & $7(9 \times 9)^{*}$ & 5,3 & II 2 (87) & II & Дон. II. Р. III. Г/3, 40 см & $\begin{array}{c}\text { MA РТ, Дж- } \\
\text { III-93/1098 }\end{array}$ & 4,8 \\
\hline 23 & 51 & 16 & 35 & $\begin{array}{c}7(10 \times \\
10)^{*} \\
\end{array}$ & 5,3 & II 2 (87) & III & Дон. II. Р. III. А/5, 75 см & БГИАЗ-588-2291/245 & 4,9 \\
\hline 24 & 65 & 36 & 29 & $6(8 \times 8)^{*}$ & 4,5 & II $3(88)$ & II & Дон. ІІ. Р. V. А/2, 40 см & МА РТ, Дж-V-94/5 & 4,10 \\
\hline 25 & 45 & 25 & 20 & $\begin{array}{c}7(10 \times \\
10)^{*} \\
\end{array}$ & 2,5 & II $3(88)$ & I & Дон. ІІ. П. м. & МА РТ, Дж-1511 & 4,11 \\
\hline 26 & 51 & 28 & 23 & $7(9 \times 9)^{*}$ & 4,7 & II 4 (91) & III & Дон. II. Р. V. В/2, 60 см & МА РТ, Дж-V-94/4 & 4,12 \\
\hline 27 & 88 & 44 & 44 & $7(11 \times 8)^{*}$ & 11,8 & $\begin{array}{c}\text { II } 5(97, \\
4)\end{array}$ & II & Гор. Р. II & БГИАЗ-245-1025 & 4,13 \\
\hline 28 & 74 & 32 & 42 & $7(12 \times 7)^{*}$ & 8,8 & $\begin{array}{c}\text { II } 5(97, \\
4)\end{array}$ & II & Дон. II. Р. V. А/5, 40 см & МА РТ, Дж-V-94/6 & 4,14 \\
\hline \begin{tabular}{|l|}
29 \\
$* * *$ \\
\end{tabular} & 90 & 50 & 40 & $16 \times 10$ & 12,4 & II 6 (100) & II & Дон. II. Р. V. В/2, 25 см & МА РТ, Дж-V-94/54 & 4,15 \\
\hline 30 & 83 & 42 & 41 & $8 \times 8$ & 11,8 & II $6(100)$ & I & П. м. & МУГЧ & 4,16 \\
\hline 31 & 75 & 32 & 43 & $8 \times 8$ & 9,6 & II 6 (100) & & Гор. Р. I (?) & БГИАЗ-245-735 & 4,17 \\
\hline 32 & 70 & 30 & 40 & $10 \times 6$ & 8,9 & II 7 & III & Дон. II. Р. V. Г/4, 50 см & MA РТ, Дж-V-94/7 & 4,18 \\
\hline
\end{tabular}

Прим.: * макс. иирина грани/ расст. между противоположными ребрами; ** в верхней части боевой головки; *** согнут. 
Таблица 2. Хронология наконечников стрел Джукетау

Table 2. Chronology of Juketau arrowheads

\begin{tabular}{|l|l|l|l|l|l|l|l|l|l|}
\hline $\begin{array}{l}\text { Tun, вид/ } \\
\text { время (в8. }\end{array}$ & VIII & IX & $X$ & $X I$ & XII & \multicolumn{2}{|l|}{ XII } & XIV & Место находки \\
\hline I 1 (37) & & & & & & & & & Дон. II* \\
\hline I 4 (46?) & & & & & & & & & Дон. II* \\
\hline I 5 (48) & & & & & & & & & Дон. II \\
\hline II 1 (83) & & & & & & & & & Гор. \\
\hline II 1 (83) & & & & & & & & & Гор. \\
\hline II 1 (83) & & & & & & & & & Дон. II ? \\
\hline II 1 (83) & & & & & & & & & Дон. II \\
\hline II 1 (83) & & & & & & & & & Дон. II \\
\hline II 1 (83) & & & & & & & & & Дон. II* \\
\hline II 1 (83) & & & & & & & & & Крут. ?* \\
\hline II 1 (83) & & & & & & & & & Крут. ?* \\
\hline II 3 (88) & & & & & & & & & Дон. II* \\
\hline II 3 (88) & & & & & & & & & Дон. II \\
\hline II 4 (91) & & & & & & & & & Дон. II \\
\hline II 6 (100) & & & & & & & & & Гор. \\
\hline II 6 (100) & & & & & & & & & Дон. II \\
\hline II 6 (100) & & & & & & & & & Крут. ?* \\
\hline II 7 & & & & & & & & & Дон. II \\
\hline II 2 (87) & & & & & & & & & Дон. II \\
\hline II 2 (87) & & & & & & & & & Дон. II \\
\hline I 2 (38, 3) & & & & & & & & Гор. \\
\hline I 6 (66) & & & & & & & & & Дон. II* \\
\hline I 7 (67) & & & & & & & & & Дон. II \\
\hline I 7 (67) & & & & & & & & & Дон. II \\
\hline I 7 (67) & & & & & & & & & Дон. II \\
\hline I 7 (67) & & & & & & & & & Дон. II \\
\hline I 7 (67) & & & & & & & & & Дон. II \\
\hline I 8 (69) & & & & & & & & & Дон. II \\
\hline I 9 (72) & & & & & & & & & Крут. ?* \\
\hline II 5 (97, 4) & & & & & & & & & Гор. \\
\hline II 5 (97, 4) & & & & & & & & & Дон. II \\
\hline
\end{tabular}

* - подъемный материал

- общее время бытования/ более характерно

Гор. - городище. Крут - Крутогорское (Донауровское I) селище.

Дон II-Донауровское селище II.

но, детали лука. Детали колчана представлены тремя находками с территории Донауровского селища II - железным крючком из золотоордынского слоя (Дон. II, p. III, Б/8, 40 см; БГИАЗ-245-2001), железной петлей из домонгольского слоя (Дон. II, p. III, Г/4, 80 см; MA PТ, Дж-III-93/1090), костяным облом- ком накладки (Дон.II, П.м.; МА РТ, Дж-781). Обломок костяной петли (Гор., p. III, соор. 4, домонгольский слой; БГИАЗ-245-1735) может являться деталью крепления налучья к саадачному поясу. Простой колчанный крючок длиной 40 мм имеет подвижное кольцо диаметром 15 мм, цевье 25 мм (рис. 1:4). 


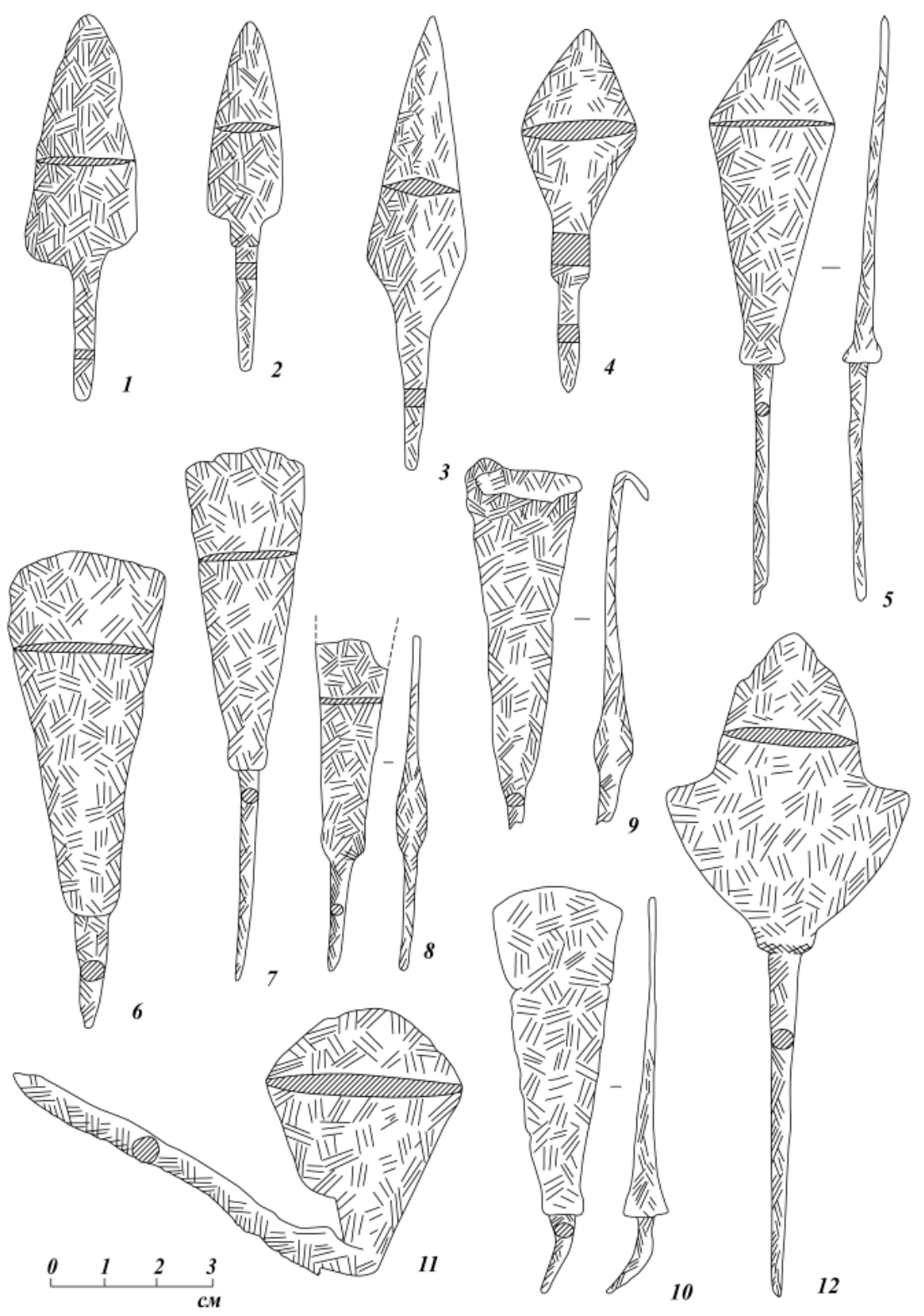

Рис. 3. Железные наконечники стрел. Тип I

Fig. 3. Iron arrowheads. Type I

Он явно служил для крепления колчана к поясу. Петля представляет собой железный стержень П-образной формы с расплющенными концами (рис. 1:3). Обломок накладки имеет вид узкой пластины шириной 10 мм и толщиной 2 мм с двумя отверстиями диаметром по 3 мм, расположенными на расстоянии 35 мм друг от друга (рис. 1:2). Соответствует типу 2 по типологии Ф.Ш. Хузина по материалам коллекций из Билярского городища (Культура Биляра, табл. XLVII: 6, с. 137). Обломок костяной петли имеет ширину 2 см и толщину 3 мм, на нем фиксируется четыре отверстия диаметром по 4 мм, в том числе два совмещенных (рис. 1:1). Есть основания полагать, что это обломок детали обкладки колчана (Культура Биляра, с. 135), которая может датироваться XIII-XIV вв.
Железные наконечники стрел найдены во всех частях комплекса Джукетау (табл. 1). Обращает на себя внимание их повышенное количество на раскопе V Донауровского селища II. Некоторые из наконечников имеют хорошую стратиграфическую привязку. Так, один из экземпляров наконечников типа $67^{1}$ был обнаружен в раскопе II Донауровского селища II «при вскрытии слоя пожарища, завершающего III стратиграфический пласт» (Хлебникова, 1975 , с. 238 , рис. $3: 1$ ). Интересно, что практически единственными с территории городища и прилегающей к нему территории находками, характерными для второй половины XIII - XIV вв., являются несколько наконечников стрел, близкие к типам 38:3, 97:4, 72 («срезень») $)^{2}$. При этом, исходя из функционального назначения этой категории нахо- 

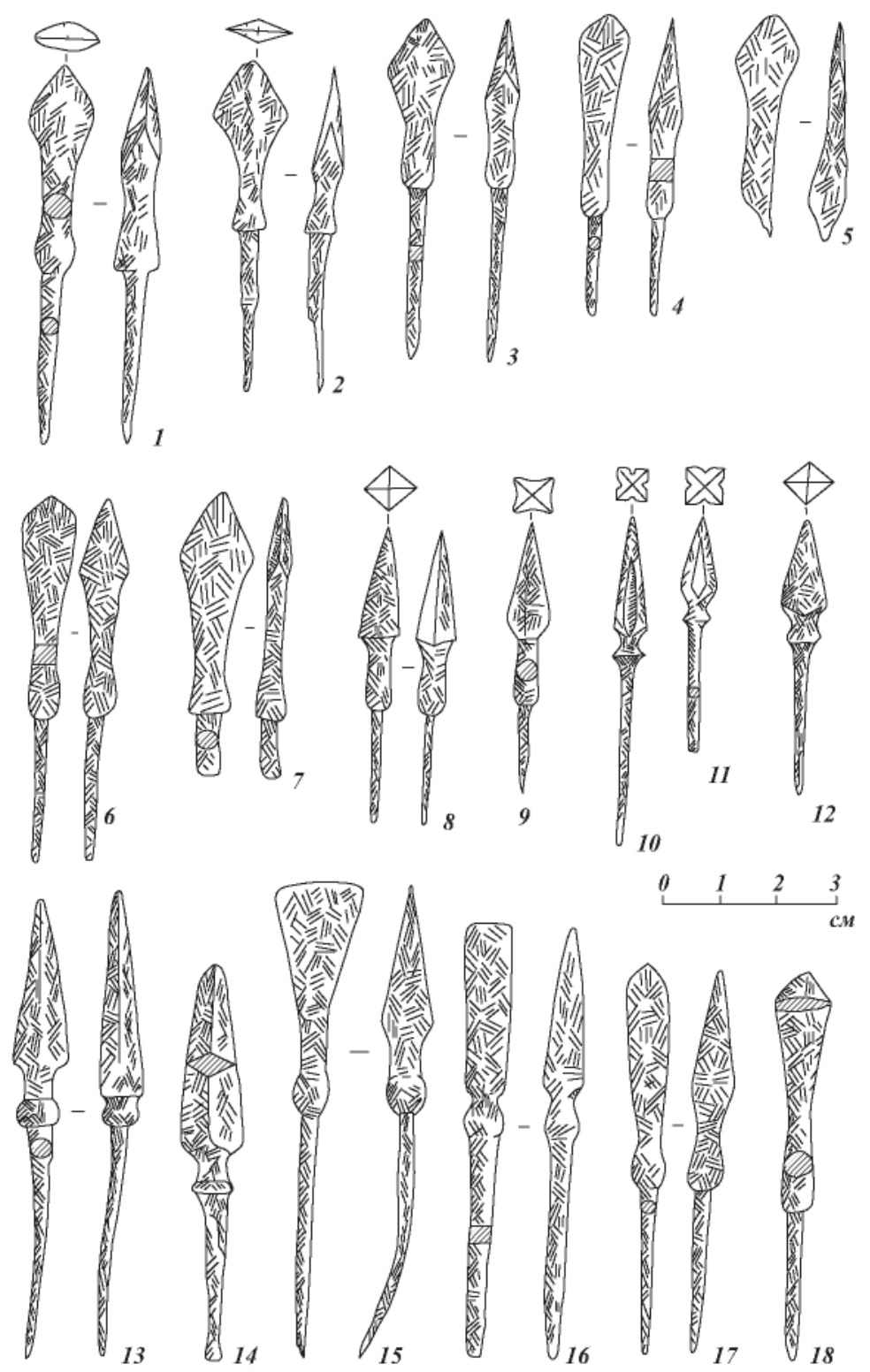

Рис. 4. Железные наконечники стрел. Тип II

Fig. 4. Iron arrowheads. Type II

док и на фоне отсутствия других археологических материалов золотоордынского времени, наконечники эти, скорее, не датируют золотоордынский слой, а завершают домонгольский (Набиуллин, 2001, с. 49).

Bce известные наконечники из средневекового слоя городища Джукетау черешковые. По форме поперечного сечения пера делятся на две группы: I - плоские (линза, вытянутый ромб), II - граненые (бронебойные). Типы выделяются по форме пера и его пропорциям (у плоских), решению перехода пера к черешку и пр.

Группа I. Плоские.

Тип 1 (37) - треугольный, пропорции пера 1:2,5 (1 экз., рис. 3:1). Были в употреблении с VIII по XIV вв.

Тип 2 (38, вид 3) - килевидный, пропорции пера 1:3,3 (1 экз., рис. 3:2). Употреблялись в
XIII-XIV вв., возможно, и во второй половине XII в.

Тип 3 (подобный типу 46) - ромбовидный «новгородского типа», пропорции пера 1:3 (1 экз., рис. 3:3). Широкое распространение имели в IX-XI вв., но бытовали по XIII в. включительно.

Тип 4 (48) - ромбический с упором, пропорции пера 1:2,5 (1 экз., рис. $3: 4)$. Были в употреблении с IX по XIV вв.

Тип 5 (66) - срезень веслообразный, пропорции пера 1:3 (1 экз., рис. 3:5). Бытовали во второй половине XIII - XIV вв.

Тип 6 (67) - томары - наконечники стрел в виде узкой вытянутой лопаточки, пропорции пера 1:2 - 1:3 (5 экз., рис. 3: 6-10). В памятниках Тувы, Прибайкалья, Забайкалья, Монголии (Худяков, 1990, с. 104-106, рис. 54: 4,10; $55: 4,5,8 ; 56,1,6-8,10-12 ; 57: 5,7,8)$ датируют- 
ся IX-XIV вв. В Восточной Европе бытовали во второй половине XII -XIV вв.

Тип 7 (69) - срезень джучидский, пропорции пера 1:1,6 (1 экз., рис. 3:11). Бытовали во второй половине XIII-XIV вв.

Тип 8 (72) - срезень кунжутолистный, пропорции пера 1:1,4 (1 экз., рис. 3:12). В Центральной Азии известны из памятников Хакасско-Минусинской котловины (Губайдуллин, Измайлов, 1990, с.111, рис.VI: 1,2), Прибайкалья, Забайкалья, Монголии (Худяков, 1990, с. $112-113$, рис. $54: 2,8 ; 57: 2,3 ; 60$, 1,2; 61: 4,6), где датируются IX-XIV вв. В памятниках Восточной Европы бытовали во второй половине XIII - XIV вв.

Группа II. Граненые (бронебойные).

Тип 1 (83) - с массивной боевой головкой ромбовидных очертаний и ромбического (подовально-ромбического) сечения, с шейкой (9 экз., рис. 4:1-7). Наиболее многочисленны. Каждая находка имеет свою индивидуальность (размеры; большая или меньшая боевая головка, круглые или подквадратные шейка, черешок). Сюда же мы склоняемся включить и три опубликованных наконечника, отнесенные к типу 52:2 (Хлебникова, 1975, рис. 4: 4-6). Наконечники данного типа очень характерны для XI в. Довольно редко встречаются в памятниках Центральной Азии и датируются IX-XIV вв. (Худяков, 1990, с. 114, рис. 62: 8, 13).

Тип 2 (87) - пирамидальные ромбического сечения, с круглой шейкой (2 экз., рис. $4: 8,9)$. Сечение черешка у одного экземпляра прямоугольное, У второго четко не выделяется. У одной находки (рис. 4: 9) есть слабо выраженные насечки по плоскостям боевой головки. В целом подобные экземпляры датируются XII-XIV вв., хотя находки из Билярского городища и наши экземпляры позволяют отнести ко второй половине XII - первой трети XIII вв.

Тип 3 (88) - пирамидальные квадратного сечения с желобками на гранях боевой головки (2 экз., рис. 4: 10,11). Сечение черешка первого экземпляра квадратное, второго круглое. Второй экземпляр миниатюрный. Были распространены в X-XIV вв.

Тип 4 (91) - пирамидальный с массивной короткой боевой головкой ромбического сечения и с перехватом у черешка (1 экз., рис. 4:12). Имеют широкий хронологический диапазон бытования - с X по XIV вв.

Тип 5 (97, вид 4) - бронебойные в виде кинжальчика ромбического сечения с перехватом (2 экз., рис. 4: 13,14). Были распространены также широко, в X-XIV вв., экземпляры из Джукетау датируются предположительно XIII-XIV вв.

Тип 6 (100) - долотовидные (3 экз., рис. 4: 15-17). Разделяются по решению боевой головки по одному из продольных сечений. Перо первого экземпляра расширяется в верхней части и имеет незаостренное завершение (рис. 4:15); второго - примерно одинаковую ширину по всей длине и незаостренное завершение (рис. 4:16); третьего - слабое расширение в верхней части и заостренное завершение (рис. 4:17). Черешки первых двух имеют квадратное, последнего круглое сечения. Были широко распространены в домонгольское время начиная с середины XI в.

Тип 7 - долотовидный. Близок к типу 6 (100), но отличается заостренным завершением боевой головки в обеих сечениях, что делает его похожим на тип 1 (83) (рис. 4: 18). Шейка и черешок круглые в сечении.

Таким образом, комплекс наконечников условно можно разделить на две группы. В первую входят наконечники стрел преимущественно подквадратные или ромбические в сечении с упором у основания черешка и плоскими или линзовидными в сечении, как правило листовидных, кунжутолистных или секторовидных форм. Наконечники первой группы в большинстве случаев датируются булгарским временем (X-XIII вв.) и практически не находят аналогий в средневековых памятниках Центральной Азии. Наконечники второй группы датируются или довольно широко, либо золотоордынским временем, а также часто находят аналогии в могильниках средневековых кочевников Центральной Азии, и, следовательно, могли попасть в Восточную Европу как элемент татаромонгольского стрелкового набора. В определенной мере это доказывает, что в период становления Улуса Джучи произошла смена типов лука и самого способа стрелометания.

Оружие ближнего боя представлено обломанным железным перекрестием сабли из домонгольского сооружения (рис. 1:5), переотложенным железным втоком (рис.1:7) с территории Донауровского селища II (Дон.II, П.м.; МА РТ, Дж-1442)3. Перекрестие сабли с боковым расширением в середине имеет длину примерно 10 см, ширину 3 см, высоту от 0,6 см до 1,1-1,2 см в месте расширения (Дон. II, p. VI, соор. 3, домонгольский слой; МА РТ, Дж-96-VI/550). На территории Джукетау найдены также обломки железных топоров (Хлебникова, 1975, рис. 4: 14; и 
др.), принадлежность которых к рабочим или универсальным походно-бытовым точно не устанавливается.

Предположительно боевыми являются два ножа с прямой спинкой, выраженным переходом черешка к лезвию (клинку). Первый (Дон. II. П.м.; МА РТ, Дж-94/3) имеет общую длину 37 см (длина лезвия 27 см), ширину лезвия до 2,8 см и толщину до 0,9 см (рис. 1: 9; рис. 4); второй (Дон. ІІ. П.м.; МА РТ, Дж-1510) обломан и имеет прослеживаемую ширину лезвия до 4,3 см и толщину до 0,5 см (рис. 1: 8). Оба этих ножа, судя по длине и ширине клинка, являются, видимо, не хозяйственными, а боевыми клинками, своего рода дополнительным походно-боевым оружием, поскольку в хозяйстве использовались более короткие и узкие ножи.

Предметом защитного вооружения является переотложенная находка фрагмента железной кольчуги (Дон. II, p.VI, А/14, 20 см; МА PT, Дж-VI-95/12) с территории Донауровского селища II, от которой сохранилось шесть плоских соединенных друг с другом круглых и подовальных колец диаметром 12-14 мм и средней толщиной 0,5 мм (рис. 1: 6). Среди многочисленных одиночных колец также могут оказаться кольчужные, а среди обломков тонких железных пластинок - детали пластинчатых доспехов.

Интерес представляют результаты исследования технологии изготовления пока небольшой серии наконечников стрел по данным металлографических анализов. Среди семи наконечников стрел аналитически были выявлены шесть технологических схем: из простого кричного железа, из сырцовой неравномерно науглероженной стали, цементация, из заготовки пакетного металла, двух- и трехслойная железо-стальная сварка. Кроме этого, были исследованы поперечные срезы кольчужного кольца и заклепки от него. Микроструктурный анализ показал, что они были откованы из очень тщательно прокованного кричного железа. При этом для получения круглого и тонкого в диаметре профиля проволоки заготовки применялась операция волочения, в результате чего произошло образование очень мелкозернистой ферритовой микроструктуры, практически не содержащей неметаллические и шлаковые включения. Сборка колец в кольчужное полотно производилась с применением операции клепки специально изготовленными железными клепочками с грибовидной шляпкой. Для выполнения этой операции использовалось специальное оборудование, состоящее из наковаленки с гнездом для головки клепки и специального обжимника (Семыкин, Набиуллин, 2007, с. 100-109). В настоящее время продолжается изучение технологии изготовления представительной выборки кузнечной продукции Джукетау по данным металлографических анализов, в том числе предметов вооружения.

В рассмотренных материалах выделяются две хронологические группы, относящиеся к домонгольскому (X - первая треть XIII вв.) и золотоордынскому (вторая треть XIII-XIV вв.) периодам. Часть изделий имеет широкий хронологический диапазон бытования, однако в некоторых случаях возможно уточнение датировок исходя из археологического контекста происхождения материала.

Вопрос о местном или внешнем происхождении отдельно взятых предметов вооружения остается открытым и усложняется в том числе и исходя из функционального назначения этой категории находок. Во всяком случае, в коллекции имеется несколько железных предметов, в которых по некоторым признакам угадываются заготовки наконечников стрел.

Комплекс находок вооружения из Джукетау содержит сравнительно небольшое количество специализированного оружия, пока не выявлено наконечников копий, ударно-дробящего (булавы, кистени) оружия. В значительной степени он сохранился в виде железных наконечников стрел. Это вполне ожидаемо для «расходных» предметов метательного вооружения (примерно так же происходило и при охоте), которые археологизировались, как правило, в период боевых столкновений. Предметы вооружения и в целом вещи из железа имели высокую стоимость, а дорогие виды оружия ближнего боя и защитного снаряжения являлись достоянием сословия военно-служилой аристократии, чем в том числе объясняется их редкость.

Пока не представляется возможным уверенно связывать отдельно взятые археологические предметы вооружения с конкретными историческими событиями - монгольским нашествием, набегами ушкуйников и русских князей, другими поздне- и постзолотоордынскими событиями. Заманчивой видится перспектива сравнить представительные выборки предметов вооружения из памятников, исторически известных в связи с конкретными военными событиями (Измайлов, Недашковский, 1993, с. 72-86; и др.). 


\section{Примечания:}

1 Здесь и далее типы и их базовая хронология даны по монографии А. Ф. Медведева (1966). Сводная хронология наконечников стрел приводится в табл. 2.

${ }^{2}$ Наконечник типа 38:3 может иметь более широкую датировку.

${ }^{3}$ Еще один опубликованный как происходящий из Джукетау вток (Измайлов, 1997, рис. 35, 5, табл. VIIIa, № 6) в фондах Национального музея РТ имеет этикетку с дополнительной надписью: «Елантово».

\section{ЛИТЕРАТУРА}

Горелик М.В., Измайлов И.Л. Вооружение // История татар с древнейших времен в семи томах Т. III. Улус Джучи (Золотая Орда). XIII - середина XV в. / Науч. ред. М.А. Усманов. Казань: ИИ АН РТ, 2009. C. $396-405$.

Губайдуллин А. М., Измайлов И. Л. Коллекция железных наконечников стрел из Хакасско-Минусинской котловины музея археологии Казанского университета // Военное дело древнего и средневекового населения Северной и Центральной Азии / Отв. ред. Ю.С. Худяков. Новосибирск: НГУ, 1990. С. 106-120.

Измайлов И.Л. Вооружение и военное дело населения Волжской Булгарии X - начала XIII в. КазаньМагадан: СВНЦ ДВО РАН, 1997. 212 с.

Измайлов И. Л. Военное дело // История татар с древнейших времен в семи томах. Том II. Великая Булгария и Великая Степь. / Отв. ред. Ф.Ш. Хузин. Казань: Изд-во РухИЛ,, 2006. С. 336-367.

Измайлов И. Л., Недашковский Л. Ф. Находки предметов вооружения с территории золотоордынского города Укека из музеев Казани и Саратова // Из истории Золотой Орды. Казань: Фонд им. М. Султан-Галиева, 1993. С. 72-86.

Культура Биляра. Булгарские орудия труда и оружие X-XIII вв. / Отв. ред. А.Х. Халиков. М.: Наука, 1985. $216 \mathrm{c}$.

Медведев А. Ф. Ручное метательное оружие (лук и стрелы, самострел). VIII-XIV вв. / САИ. Вып. Е1-36. М.: Наука, 1966. 184 с.

Набиуллин Н.Г. Город Джукетау по итогам новых исследований // Научное наследие А.П. Смирнова и современные проблемы археологии Волго-Камья. Материалы науч. конф. / Труды ГИМ. Вып. 122. / Отв. ред. И.В. Белоцерковская. М.: 2000. С. 286-293.

Набиуллин Н.Г. Город Джукетау в XIII-XIV вв. (к проблеме перехода домонгольского города в золотоордынский) // ТА. 2001. № 1-2 (8-9). С. 47-63.

Набиуллин Н.Г. Из истории формирования коллекций Джукетау // Археология Евразийских степей. 2019. № 5. C. 24-29.

Pуденко K.A. Железные наконечники стрел VIII-XV вв. из Волжской Булгарии. Казань: Заман, 2003. $512 \mathrm{c}$.

Савченкова Л. Л. Черный металл города Болгара // Город Болгар: Ремесло металлургов, кузнецов, литейщиков / Отв. ред. Г.А. Федоров-Давыдов. Казань: ИЯЛИ им. Г. Ибрагимова АН Татарстана, 1996. C. 5-88.

Семыкин Ю. А., Набиуллин Н. Г. Технология изготовления кузнечной продукции с городища Джукетау по данным металлографических анализов // Краеведческие записки: Сборник научных трудов областной научной конференции «История и современность Симбирского-Ульяновского края. Ульяновск - 2006». Вып. 13. Ульяновск, 2007. С. 100-109.

Хлебникова Т.А. К истории Жукотина (Джуке-тау) домонгольской поры (по работам 1970-1972 гг.) // CA. 1975. №1. С. 234-251.

Худяков Ю.С. Вооружение Центральноазиатских кочевников в эпоху раннего и развитого средневековья. Новосибирск: Наука, 1991. 190 с.

\section{Информация об авторах:}

Набиуллин Наиль Гатиатуллович, кандидат исторических наук, старший научный сотрудник, Институт археологии им. А.Х. Халикова АН РТ (г. Казань, Россия); arheotat@mail.ru

Измайлов Искандер Лерунович, доктор исторических наук, главный научный сотрудник, Институт археологии им. А.Х. Халикова АН РТ (г. Казань, Россия); ismail@inbox.ru

\section{REFERENCES}

Gorelik, M. V., Izmailov, I. L. 2009. In Usmanov, M. A. (ed.). Istoriia tatar s drevneishikh vremen v semi tomakh. Tom III: Ulus Dzhuchi (Zolotaia Orda). XIII-seredina XV (History of the Tatars since Ancient Times in seven volumes. Volume 3: The Ulus of Jochi (the Golden Horde). $13^{\text {th }}-$ mid. $15^{\text {th }} \mathrm{cc}$.). Kazan: Institute of History named after Shigabuddin Mardzhani, Tatarstan Academy of Sciences, 396-405 (in Russian). 
Gubaidullin, A. M., Izmailov, I. L. 1990. In Khudiakov, Yu. S. (ed.). Voennoe delo drevnego i srednevekovogo naseleniia Severnoi i Tsentral'noi Azii (Military Art of the Ancient and Medieval Population of Northern and Central Asia). Novosibirsk: Novosibirsk State University, 106-120 (in Russian).

Izmaylov, I. L. 1997. Vooruzhenie i voennoe delo naseleniya Volzhskoy Bulgarii X-nachala XIII v. (Armament and Warfare of the population of Volga Bulgaria $10^{\text {th }}$ - beginning of $13^{\text {th }}$ century) Kazan-Magadan: North-East Scientific Center, Russia Academy of Sciences Far East Branch (in Russian).

Izmailov, I. L. 2006. In Khuzin, F. Sh. (ed.). Istoriya tatar s drevnejshih vremen (v semi tomah) (History of The Tatars Since Ancient Times (in Seven Volumes). 2 Kazan: "RukhIL" Publ., 336-367. (in Russian).

Izmailov, I. L., Nedashkovskii, L. F. 1993. In Iz istorii Zolotoi Ordy (From the History of the Golden Horde). Kazan: M. Sultangaliev Foundation, 72-86 (in Russian).

Khalikov, A. Kh. (ed.). 1985. Kul'tura Biliara. Bulgarskie orudiia truda i oruzhie X-XIII vv. (Bilyar Culture. Bulgar Tools and Weapons in 10 $10^{\text {th }}-13^{\text {th }}$ Centuries). Moscow: "Nauka" Publ. (in Russian).

Medvedev, A. F. 1966. Ruchnoe metatel'noe oruzhie (luk i strely, samostrel) VIII-XIV vv. (Hand Missile Weapons (Bow and Arrows, Crossbow) of $8^{\text {th }}-14^{\text {th }}$ Centuries). Svod Arkheologicheskikh Istochnikov (Corpus of Archaeological Sources) E1-36. Moscow: "Nauka" Publ. (in Russian).

Nabiullin, N. G. 2000. In Belotserkovskaia, I. V. (ed.). Arkheologicheskii sbornik. Pogrebal'nyi obriad (Archaeological Collection of Papers. Funeral Rite). Series: Proceedings of the State Historical Museum 122. Moscow: State Historical Museum, 286-293 (in Russian).

Nabiullin, N. G. 2001. In Tatarskaia arkheologiia (Tatar Archaeology) 8-9 (1-2), 47-63 (in Russian).

Nabiullin, N. G. 2019. In Arkheologiia Evraziiskikh stepei (Archaeology of Eurasian Steppes) 5, 24-29 (in Russian).

Rudenko, K. A. 2003. Zheleznye nakonechniki strel VIII-XV vv. iz Volzhskoi Bulgarii. Issledovanie $i$ katalog (Iron Arrowheads of the $8^{\text {th }}-15^{\text {th }}$ Centuries from the Volga Bulgaria. Studies and Catalogue). Kazan: "Zaman" Publ. (in Russian).

Savchenkova, L. L. 1996. In Fedorov-Davydov, G. A. (ed.). Gorod Bolgar. Remeslo metallurgov, kuznetsov, liteishchikov (Town of Bolgar. Craft of Metallurgists, Smiths, Founders). Kazan: Institute for Language, Literature and History Institute named after G. Ibragimov, Academy of Sciences of Tatarstan, 5-88 (in Russian).

Semykin, Yu. A., Nabiullin, N. G. 2007. In. Kraevedcheskie zapiski (Notes on Local History) 13. Ul'ianovsk: "Korporatsiia tekhnologii prodvizheniia" Publ., 100-109 (in Russian).

Khlebnikova, T. A. 1975. In Sovetskaia Arkheologiia (Soviet Archaeology) (1), 234-251 (in Russian).

Khudyakov, Yu. S. 1991. Vooruzhenie tsentral'noaziatskikh kochevnikov v epokhu rannego i razvitogo srednevekov'ya (Armament of Central Asian Nomads in the Early and Developed Middle Ages). Novosibirsk: "Nauka" Publ. (in Russian).

\section{About the Authors:}

Nabiullin Nail G. Candidate of Historical Sciences. Institute of Archaeology named after A. Kh. Khalikov, Tatarstan Academy of Sciences. Butlerov St., 30, Kazan, 420012, the Republic of Tatarstan, Russian Federation; arheotat@mail.ru

Izmaylov Iskander L. Doctor of Historical Sciences. Institute of Archaeology named after A. Kh. Khalikov, Tatarstan Academy of Sciences. Butlerov St., 30, Kazan, 420012, Republic of Tatarstan, Russian Federation; ismail@inbox.ru 